Metal-Catalyzed

Asymmetric

Synthesis and

Stereoselective

Reactions

\section{Palladium-Catalyzed Reductive Heck Reaction}
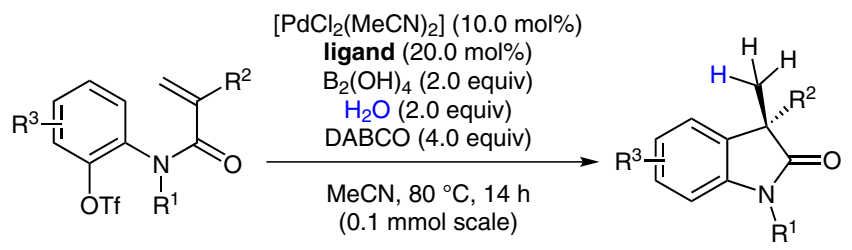

28 examples $62-90 \%$ yield 69-94\% ee

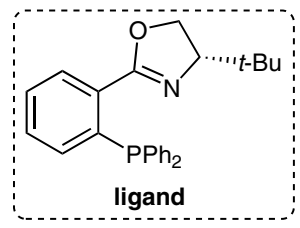

Selected examples:<smiles>COc1ccc([C@]2(C)C(=O)N(C)c3ccccc32)cc1</smiles>

$86 \%$ yield $90 \%$ ee<smiles>CN1C(=O)[C@@](C)(c2ccccc2)c2ccccc21</smiles>

$87 \%$ yield $90 \%$ ee<smiles>Cc1ccc2c(c1)N(C)C(=O)[C@]2(C)c1ccccc1</smiles>

$82 \%$ yield $90 \%$ ee<smiles>COc1ccc2c(c1)N(C)C(=O)[C@]2(C)c1ccccc1</smiles>
$88 \%$ yield<smiles>CC1(c2ccc(Cl)cc2)C(=O)N([N+](=O)[O-])c2ccccc21</smiles>
$94 \%$ ee<smiles>CC1(c2ccc(F)cc2)C(=O)N([N+](=O)[O-])c2ccccc21</smiles>

$90 \%$ yield $90 \%$ yield
$90 \%$ ee<smiles>CN1C(=O)[C@@](C)(CN(Cc2ccccc2)Cc2ccccc2)c2ccccc21</smiles>

$72 \%$ yield $77 \%$ ee<smiles>Cc1ccccc1C1(C)C(=O)N(C)c2ccccc21</smiles>

$87 \%$ yield $92 \%$ ee<smiles>CCOC(=O)C1(C)c2ccccc2N1[N+](=O)[O-]</smiles>

\section{$84 \%$ yield}<smiles>CN1C(=O)[C@]2(CCC(C)(C)C2)c2ccccc21</smiles>

$75 \%$ yield $70 \%$ ee

\section{Key words}

palladium catalysis

reductive Heck

reaction

oxindoles

hydride source

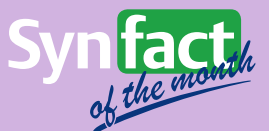

Reactions performed with $\mathrm{D}_{2} \mathrm{O}$ and $\mathrm{B}_{2} \mathrm{Cat}_{2}$ :<smiles>CN1C(=O)C(O)(c2ccc(F)cc2)c2ccccc21</smiles>

$68 \%$ yield $90 \%$ ee $92 \% \mathrm{D}$ incorporation<smiles>CN1C(=O)[C@@](C)(c2cccc(Cl)c2)c2ccccc21</smiles>

$63 \%$ yield $90 \%$ ee 95\% D incorporation<smiles>Cc1ccccc1C1(C)C(=O)N(C)c2ccccc21</smiles>

$67 \%$ yield $92 \%$ ee 90\% D incorporation
Significance: Water represents the cheapest and most environmentally benign source of hydrogen or hydride; therefore, its use in combination with transition-metal catalysis is very appealing. In the present work, the authors present a palladiumcatalyzed enantioselective reductive Heck reaction using water as final hydride donor.

SYNFACTS Contributors: Mark Lautens, Ivan Franzon Synfacts 2017, 13(05), 0495 Published online: 18.04.2017 Dol: 10.1055/s-0036-1590330; Reg-No.: L02717SF
Comment: $\mathrm{N}$-Aryl acrylamides reacted in the presence of a $\left[\mathrm{PdCl}_{2}(\mathrm{MeCN})_{2}\right]$ catalyst and $(\mathrm{S})$ - $t$ BuPHOX ligand to generate the corresponding products in good yields and good enantioselectivities using water as hydride source. The use of DABCO as a base and a catalytic amount of $\mathrm{B}_{2}(\mathrm{OH})_{4}$ was found to be crucial for the success of the transformation. The use of deuterium oxide allowed the synthesis of D-labeled oxindoles with $>90 \%$ D incorporation. 